\title{
THE EFFECT OF PERCEIVED EASE OF USE AND PERCEIVED SECURITY TOWARD SATISFACTION AND REPURCHASE INTENTION
}

\author{
Nicholas Wilson $^{1 *}$, Meilisa Alvita ${ }^{2}$, Jensen Wibisono ${ }^{3}$ \\ ${ }^{1}$ Faculty of Social Sciences and Humanities, Department of Management, Universitas Bunda Mulia, Jakarta \\ Email: nicholaswilson8989@gmail.com \\ ${ }^{2}$ Faculty of Social Sciences and Humanities, Department of Management, Universitas Bunda Mulia, Jakarta \\ Email:malvita@bundamulia.ac.id \\ ${ }^{3}$ Faculty of Social Sciences and Humanities, Department of Management, Universitas Bunda Mulia, Jakarta \\ Email:jensen.wibisono@yahoo.com \\ *penulis korespondensi
}

Masuk : 11-01-2021, revisi: 28-01-2021, diterima untuk diterbitkan : 01-02-2020

\begin{abstract}
ABSTRAK
Penelitian ini dilakukan guna mengetahui bagaimana pengaruh Perceived Ease of Use dan Perceived Security terhadap Customer Satisfaction dan Repurchase Intention pada sektor B2C E-Commerce di Indonesia. Penelitian ini menggunakan metode survei, dimana, kuesioner dipilih sebagai metode untuk mengumpulkan data yang diperlukan pada penelitian ini. Sebanyak 250 responden berpartisipasi pada penelitian ini, dimana, dari 250 data yang terkumpul, sebanyak 226 data dinyatakan Valid dan Reliable, sehingga dapat digunakan untuk selanjutnya diproses pada penelitian ini. Data yang telah dinyatakan Valid dan Reliable selanjutnya akan dianalisa dengan metode PLSSEM. Berdasarkan hasil analisis data yang telah dilakukan, peneliti dapat menyimpulkan bahwa Perceived Ease of Use dan Perceived Security terhadap Customer Satisfaction dan Repurchase Intention pada sektor B2C ECommerce di Indonesia. Adapun hasil dari penelitian ini menunjukkan bahwa penting bagi setiap perusahaan B2C E-Commerce di Indonesia di dalam menciptakan suatu sistem e-commerce yang aman yang mampu melindungi para pembeli serta penjual dari kemungkinan akan munculnya kasus pencurian data ketika kedua belah pihak melakukan transaksi pembelian dan penjualan pada laman e-commerce yang dikembangkan oleh perusahaan. Selain itu juga, hasil yang diperoleh pada penelitian ini juga menunjukkan bahwa penting bagi perusahaan B2C E-Commerce di Indonesia untuk dapat mengembangkan serta menciptakan serta mengimplementasikan sistem yang bukan hanya akan membuat konsumen dapat secara cepat mempelajari sistem tersebut, namun juga guna mengurangi ataupun menghilangkan kemungkinan dari munculnya kebingungan ataupun kesulitan yang konsumen alami ketika mengakses laman E-Commerce yang dikembangkan oleh pihak perusahaan.
\end{abstract}

Kata Kunci: Perceived Ease of Use; Perceived Security; Customer Satisfaction; Repurchase Intention; Sektor ECommerce di Indonesia

\section{ABSTRACT}

This study was commenced in order to assess whether or not both Perceived Ease of Use and Perceived Security positively affect Customer Satisfaction and Repurchase Intention in the B2C E-Commerce sector in Indonesia. This research implement survey method, in which questionnaires were chose as the tools which will be used to collect all of the data needed for the completion of this study. A total of 250 respondents participated in this study, in which a total of 226 valid, reliable and usable data were further analyzed using PLS-SEM method in order to generate the results and findings required to complete this study. Based on the results of the data analyses, authors would like to conclude that both Perceived Ease of Use and Perceived Security have a significant and positive impact toward Customer Satisfaction and Repurchase Intention both in a direct and indirect manner in the B2C E-Commerce sector in Indonesia. The results obtained in this study underlined the importance of building a safe and secure system by any B2C E-Commerce companies in Indonesia, in which such system will protect both the buyers and the sellers from the possibility of getting their data stolen by irresponsible parties while both the buyers and the sellers are conducting business transacations through the website. Furthermore, the results generated in this study also underline the importance of establishing and developing a user-friendly and effective e-commerce system, which not only will make it easier and faster for the users to learn about the new system installed or implemented on the website, but also will reduce or eliminate any difficulties or confusion which consumers might felt while using the systems implemented by the companies. 
Keywords: Perceived Ease of Use; Perceived Security; Customer Satisfaction; Repurchase Intention; Indonesian ECommerce Sector

\section{INTRODUCTION \\ Research Introduction}

The Indonesian E-Commerce sector had evolved to become not only one of the fastest-growing sector in Southeast Asia, but also had become one of the fastest-growing and most developed sector in the world. According to the data reported and published by CNN Indonesia in 2020 (CNNIndonesia.com, 2020), Indonesia was ranked First (\#1) as the country with the highest ecommerce adoption rate in the world, with around 90\% of Indonesians aged between 16 to 64 years old had ever bought goods or services virtually through any e-commerce websites at least once throughout their life. Moreover, the rapid development of the e-commerce sector in Indonesia could further be felt during the current COVID-19 pandemic condition, in which since a lot of Indonesians are limiting their movement or outdoor activities in order to prevent themselves from getting infected by the COVID-19 virus, many Indonesians have opted to conduct most of their purchasing activities through e-commerce, thus rapidly increasing the number of Transactional activities conducted between the sellers and the buyers, which further enable these e-commerce companies to grow and expand themselves during the current situation. Therefore, considering such facts, situations and conditions, it is no wonder that while a lot of businesses and industries are going down or collapsing due to their inability to sustain themselves during the current COVID-19 pandemic situation, e-commerce is able to become one of a few business sector or industry in Indonesia which not only be able to survive in the current COVID-19 pandemic era, but also able to experience a rapid growth during the current pandemic situation.

In regards with the rapid development of the e-commerce sector in Indonesia, technically, any ecommerce companies which conduct their business in Indonesia could fall into one of these three main classifications or types of e-commerce companies, which are Business-to-Consumer (B2C) e-commerce company, Consumer-to-Consumer (C2C) e-commerce company, or Business-toBusiness (B2B) e-commerce company, in which, whether or not a company could be classified as B2B, C2C or B2B e-commerce company was determined and fully depend on how each ecommerce company run it's business and operational activities. "Business-to-Consumer (B2C) ecommerce companies" could be understood as e-commerce companies which directly own all of the goods which they offer to the market and sell these goods to the final consumers who are interested to buy the goods offered by the companies. In this case, it could be understood that ecommerce companies which is classified as the $\mathrm{B} 2 \mathrm{C}$ e-commerce companies are the sole owners of all of the goods which they offer and sell to the consumers in the market. Meanwhile, slight different from the concept of the $\mathrm{B} 2 \mathrm{C}$ e-commerce companies, e-commerce companies which were classified as the "Consumer-to-Consumer (C2C) e-commerce companies" are e-commerce companies which act and serve as the "bridge" which mediated any transactional activities which occur between the sellers and the buyers through the e-commerce website developed by the companies. In this case, all of the goods which were sold to the buyers were owned by any individual party which act as the seller who sell their goods and services through the website, which imply that the e-commerce companies themselves are not the owners of these goods or services. Therefore, the owners of each goods or services sold on the $\mathrm{C} 2 \mathrm{C}$ e-commerce websites tend to be owned by different individuals who serve as the sellers in this website. This concept is surely in contrast with the concept of the sellers in the $\mathrm{B} 2 \mathrm{C}$ e-commerce market, in which since the e-commerce companies themselves are the owners of all of the goods and services sold to the consumers, therefore it could be understood that in the $\mathrm{B} 2 \mathrm{C}$ e-commerce market, all of the goods or services were owned by the same party, which is the e-commerce companies themselves. 
Furthermore, also different from the concept of both the $\mathrm{B} 2 \mathrm{C}$ and $\mathrm{C} 2 \mathrm{C}$ e-commerce companies, the Business-to-Business (B2B) e-commerce companies are e-commerce companies which sell all of their goods and services not to the final consumers, but specifically to the business consumers. In the other words, companies which were classified as the B2B e-commerce companies are not selling or offering consumers goods to the clients or consumers, in which they're selling business goods or services which meant to increase the productivity of their clients' or consumers' business activities, while helping these clients to achieve their goals or targets at the same time. In Indonesia itself, the B2B e-commerce sector in Indonesia was still experiencing a slower growth rate compared to both the $\mathrm{B} 2 \mathrm{C}$ or $\mathrm{C} 2 \mathrm{C}$ e-commerce sector as most Indonesians are mostly conducting their transactional activities through either the $\mathrm{B} 2 \mathrm{C}$ or $\mathrm{C} 2 \mathrm{C}$ ecommerce websites, thus resulting in the faster growth and higher amount of transactional activities experienced by both $\mathrm{B} 2 \mathrm{C}$ or $\mathrm{C} 2 \mathrm{C}$ e-commerce companies as compared to what the $\mathrm{B} 2 \mathrm{~B}$ e-commerce companies are experiencing. However, despite the slower growth rate in the $\mathrm{B} 2 \mathrm{~B}$ e-commerce sector in Indonesia, the rapidly-expanding and growing market and business conditions in Indonesia could increase the number of companies conducting their transactional acitivites through $\mathrm{B} 2 \mathrm{~B}$ e-commerce platforms in Indonesia, which could further drive and increase the growth and development rate of the Indonesian B2B e-commerce sector in the future.

Repurchase Intention had become one of the most-studied and most-developed variables within the realm of Marketing throughout the years, in which many authors had stated or argued that Repurchase Intention was one of several important variables which could ensure the stability, survivability and the success of any companies in the world regarding the businesses which these companies are conducting, regardless of which industry that these companies are doing their business in. Regarded as the antecedent of (and strongly related to) customer loyalty, Repurchase Intention could be understood as consumers' personal willingness to re-engage, re-communicate or re-buy any goods or services from the very same companies in the future. In this case, for example, if consumer " $\mathrm{A}$ " are buying goods from company " $\mathrm{Z}$ " today, then it could be concluded that repurchase intention toward the company was successfully formed within the consumer's mind if consumer " $A$ " had a strong intention to re-buy another goods or services from company " $Z$ " in the future. Repurchase intention itself had become one of the most important factor which could determine how companies could incude loyalty toward consumers' minds, as it would be impossible for consumers to become loyal toward the company if they have no intention to re-engage or re-buy any goods or services from same companies in the future. Therefore, it is important for companies to be able to increase consumers' intention to further re-buy goods or services offered by the same companies in the future, in which once consumers' repurchase intention toward the companies had been successfully formed, then there's a high chance that consumers will eventually re-buy the goods or services sold by the companies (repurchase decision), thus increasing the chance that consumers will eventually be loyal to the companies.

Furthermore, in regard with the concept of repurchase intention, the importance that this variable had toward ensuring the success and longevity of a company could further be felt within the Indonesian e-commerce sector, in which companies competing within this industry tend to offer similar products or services toward their customers, thus increasing the possibility of consumers shifting their preferences to buy products or services from one e-commerce website to another ecommerce website (Wilson and Keni, 2018; Wilson, 2018). And considering that the number ecommerce companies which are entering the Indonesian e-commerce market keep increasing 
from time to time, then it would be safe to assume that the competitiveness level between companies in this industry will intensify in the future. Therefore, it should be noted that it is truly important for e-commerce companies in Indonesia to be able to build and set some strategies, which won't only attract more consumers to buy or purchase some goods or services from the companies, but also in order to fend off the competitors, while preventing consumers to buy any goods or services from the other competing companies.

Considering the importance of establishing a strong intention to repurchase any goods of products from the same company in the future in order to maintain a company's position and dominance within the market, it should also be noted that it is also important for companies to understand several factors which could serve as the drivers or factors which could affect consumers' repurchase intention toward companies, particularly companies which involve in the Indonesian e-commerce business. In accordance with several literatures and previous studies which had assessed several factors which could positively affect the formation of repurchase intention within consumers' minds, it was found out that perceived ease of use, perceived security and customer satisfaction as several important factors which have a big role in affecting consumers' repurchase intention in the e-commerce environment. Perceived ease of use itself could be understood as consumers or people's perception regarding the technology or system implemented by a company, in which such perception was derived from people's believe and judgement on whether or not it will consume much time, costs or energy to the new technology or system implemented by a company (Trinh et al., 2020). In the other hand, perceived security could be defined as customers or people's perception and judgement regarding whether or not it is secure enough for customer to conduct some transactions with the company (Falk et al., 2016). The concept of both perceived ease of use and perceived security were important to be understood by companies in the e-commerce sector, since companies in this industry will constantly create and update all of the systems that the company implement to it's website or ecommerce application, in which companies should ensure that the new system or technology which was implemented by the company won't be too difficulty to be understood by both existing and potential customers, while at the same time, companies should also ensure that the very same technology or system is safe enough and able to protect customers' personal data, thus enabling and convincing customers to conduct their transactional activities freely and safely on the website developed by the company.

In the other hand, customer satisfaction could be understood as consumers' judgement on whether or not a company had successfully exceeded or match the expectations that consumers' had toward the company itself regarding the goods or services offered by the company (Wilson, 2020). Despite being one of the oldest and most studied or discussed variable in the field of marketing, however, it should be noted that customer satisfaction had repeatedly understood and determined to be one of the most important factor which could affect customers' judgement and actions toward the company, as customer satisfaction is one of several important drivers which positively affecting consumers' repurchase intention and loyalty. Therefore, it is important for us to further understood regarding the role that satisfaction had in affecting repurchase intention toward companies within the e-commerce sector in Indonesia.

Previous studies by Wilson (2019) and Keni (2020) had underlined the importance of both perceived ease of use and perceived usefulness toward customer loyalty and repurchase intention respectively. However, neither of these studies try to further understand the impact of perceived security toward both customer satisfaction and loyalty. Furthermore, while previous studies were choosing $\mathrm{C} 2 \mathrm{C}$ e-commerce companies as the object of the study, in the current study, authors 
were choosing B2C e-commerce companies as the object which will be thoroughly studied and analyzed in this study. Therefore, the current study is conducted in order to fill these gaps, in which authors would like to further understand how both perceived ease of use and perceived security plays an important role in affecting both customer satisfaction and repurchase intention in the Indonesian e-commerce sector.

\section{Literature Review and Hypotheses Development}

\section{Perceived Ease of Use}

Perceived ease of use could be understood as consumers or public judgement regarding the amount of effort or time which was needed in order to learn and use a new technology, in which, such judgement could be either in a form of positive judgement or negative judgement (Gefen et al., 2003; Singh et al., 2020). Positive judgement occur when consumers or people think that it would be easy to learn and understand a new technology or system, which imply that it won't require a lot of times for consumers or people to learn and understand how the new system or technology will work. However, in the other hand, consumers' judgement could also be in the form of negative judgement, in which consumers or people argue or think that a system or technology implemented by a company was too complicated, difficulty to understand and will takes quite a lot of time for consumers or people to learn about it, in which such scenario could hamper consumers or people's intention to use the new system. Therefore, in regard with the concept of perceived ease of use, it should be noted that companies should be able to ensure that all systems or technologies implemented by the company and offered to the consumers should be the ones which are easy to be understood, learned and used by consumers or people in order to increase the number of people who are using the systems developed by the companies. Similarly, Pipitwanichakarn and Wongtada (2020) also defined perceived ease of use as consumers' cognitive feelings or judgement regarding their effort to learn a new technology or system.

\section{Perceived Security}

Perceived security could be defined or understood as consumers' judgement or perception regarding whether it is secure enough for consumers to conduct a transaction using the system or services offered by a company (Ha and Phan, 2018). In the other words, perceived security deals with the fact that consumers will often judge the security or safety level of a system or technology implemented by a company (Undale et al., 2020). In regard with the concept of perceived security, it should be noted that it would be crucially and significantly important for each and every e-commerce companies to understand the concept of perceived security in a thorough manner, as consumers' judgement or perception regarding whether or not it is safe to conduct some business transactions on the e-commerce platform developed by a company could eventually affect their final decision regarding whether or not they'll buy goods or services from the company. When consumers think or argue that the system, platform or technology built and implemented by the company is secure and had a high level of security level on it, then consumers will think that it would be safe to conduct or doing some business transactions on the website since no security issue will occur from such activities (Chellappa and Pavlou, 2002; Laforet and Li, 2005). It is mainly because since both consumers and sellers are conducting their business virtually, then usually it requires both the consumers and the sellers to provide or input their personal data (such as credit card number, email and private home address, phone numbers, etc) on the website or platform developed and built by the e-commerce companies. Therefore, when consumers or sellers are unsure regarding the security or the safety of the system developed by the company, it would hinder their intention to conduct some business activities with the company, thus increasing consumers' motivation to shift their preference to conduct the business activities on the other platform developed by another e-commerce companies. 
Therefore, establishing a proper and secure e-commerce platform or system is truly essential to be conducted by an e-commerce company in enhancing consumers' level of believe and trust toward the safety of the system, in which such ability will not only increasing their chance to conduct some business transacations with the company, but also could increase their intention to keep making additional transactional or buying activities on the company's e-commerce platform or website (Roca et al., 2009).

\section{Customer Satisfaction}

Customer satisfaction could be defined as consumers' perception or judgement regarding company's ability to fulfill or exceed the expectations that consumers had toward the company (Wilson et al., 2019). In this case, consumers will only be satisfied if company could fulfill or exceed all of the expectations that consumers had regarding the performance or the quality of the product or services offered by the company. Meanwhile, when company was deemed as "failed" to offer consumers the right or appropriate products or services with the quality similar to the quality that the consumers are expecting, then it could be concluded that the company had failed to fulfill consumers' expectations toward the company, in which such scenario will cause consumers to be dissatisfied toward the effort shown by the company. Therefore, inducing or creating satisfactory feelings toward consumers' minds by offering the products or services with the quality which will exceed the expectations that consumers had was an important thing that each and every company should do which could increase the probability that consumers will become loyal toward the company, thus enabling companies to fend off their competitors, either in the short run or in the long run (Keni et al, 2020).

\section{Repurchase Intention}

Repurchase intention could be defined or understood as consumers' personal and sincere willingness to engage in another buying or transactional activities toward the same company in the future time (Langga et al., 2020; Wilson, 2020; Nadeem et al., 2020). Furthermore, Trivedi and Yadav (2020) also define repurchase intention as consumers' strong motivation to re-buy or re-use the same products or services developed or offered by the same company in the future. Moreover, in regard with the concept of repurchase intention, it should be understood that not only that company should craft an effective strategy in order to increase people's or consumers' intention or motivation to keep buying the goods or services that they need from the same company, but company should ensure that the strategy developed or crafted by the company will prevent consumers from being attracted by similar services of goods offered by the competitors (Filieri et al., 2017; Wang et al., 2019).

\section{The Direct and Indirect Impact of Perceived Ease of Use and Perceived Security on Repurchase Intention through Customer Satisfaction}

Previous studies by Wilson (2019) and Keni (2020) had found out that perceived ease of use significantly and positively affecting consumers' repurchase intention and loyalty, both directly and indirectly through the existence of satisfaction within the Indonesian $\mathrm{C} 2 \mathrm{C}$ e-commerce sector. Furthermore, previous study by Tu et al., (2012) had also found out that perceived ease of use had a positive and significant impact toward both satisfaction and loyalty. Similarly, both Amin et al., (2014) and Anugrah (2020) also found out that perceived ease of use had a positive effect on both satisfaction and consumers' intention to repurchase or re-use the same service provided by the same provider or company. Moreover, previous studies by Xu (2013) and Cui et al., (2015) had concluded that there's a positive and significant impact of perceived security toward satisfaction and loyalty. Meanwhile, previous studies by Zhou et al., (2009), Shams et al., (2020), Garcia et al., (2020), and Slack et al., (2020) had found the significant and positive 
impact of satisfaction toward consumers' intention to repurchase toward the same company in the future. Furthermore, Ha and Pan (2018) had also found out that perceived security had a positive and significant impact toward consumers' willingness to re-engage or re-buy the same products or services from the same provider in the future. Therefore, based on these previous studies, authors would like to posit several hypotheses in this research:

H1: Perceived Ease of Use had a direct and positive impact on Repurchase Intention

H2: Perceived Security had a direct and positive impact on Repurchase Intention

H3: Perceived Ease of Use had a direct and positive impact on Customer Satisfaction

H4: Perceived Security had a direct and positive impact on Customer Satisfaction

H5: Customer Satisfaction had a direct and positive impact on Repurchase Intention

H6: Perceived Ease of Use had a direct and positive impact on Repurchase Intention through Customer Satisfaction

H7: Perceived Security had a direct and positive impact on Repurchase Intention through Customer Satisfaction

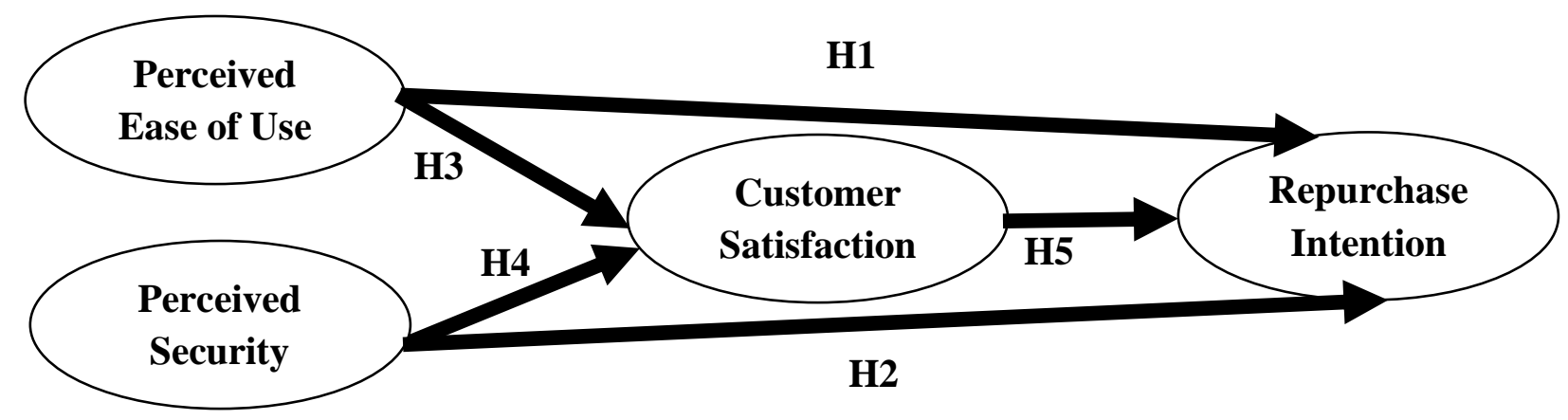

Figure 1. Research Model

Sources: Author's Personal Conception (2021)

\section{RESEARCH METHODOLOGY}

This study utilized survey method with closed-ended questionnaires were implemented as the tools which were used to collect the data required for the completion of this study from the respondents qualified and participated in this study. A total of 250 respondents participated in this study, in which all of the questionnaires then were virtually distributed to all of the respondents. The questionnaires itself were created using Google Forms Survey Tool. Respondents in this study are those who've ever bought or purchased any kinds of goods from any Business-to-Consumers (B2C) e-commerce companies in Indonesia at least 5 (five) times for the past 1 (one) year. Out of 250 questionnaires which had been distributed to the respondents, all of the respondents were filled in and returned, thus ensuring a 100\% response rate in this study. However, after further analyses, authors had to omit a total of 24 questionnaires due to incomplete responses given by the respondents, thus ensuring that a total of 226 valid, reliable and usable questionnaires could be further analyzed in this study.

Furthermore, regarding the measurements or the indicators used to assess each and every variable in this study, a total of 16 indicators representing all four variables were used in this study, in which a total of 4 indicators measuring perceived ease of use and 4 indicators measuring perceived security were adopted from Roca et al., (2009), Ha and Pan (2018) and Baccarella et al., (2020), while a total of 4 indicators measuring customer satisfaction and 4 indicators measuring repurchase intention were adopted from Oyedele et al., (2018) and Chiu and Ho (2019). Meanwhile, regarding the measurement scale implemented in this study, a 7- 
points likert scales were utilized, in which all of the respondents will give their response toward each and every indicators or statements presented on this questionnaires, in which respondents' response are ranging from " 1 ", which highlight the respondents' strong disagreement toward the statement, to "7" which highlight the respondents' strong disagreement toward the statement.

Moreover, authors' decision in determining a total of 250 respondents as the sample sizes of this study was derived from Hoogland \& Boomsma (1998) and Kline (2016) which argue that for a study which implement SEM as a method to analyze the data, 200 respondents were the minimum appropriate amount of sample sizes which a study should utilize in order to gain the necessary and accurate results desired by the author(s) of a study. Therefore, in accordance with the suggestions given by both Hoogland \& Boomsma (1998) and Kline (2016), in this study, authors had decided to implement a total of 250 respondents as the total amount of sample sizes of this study.

After gathering and filtering all of the returned data collected from all of the respondents, these data then will be analyzed using PLS-SEM method in order to assess the relationships between variables included in this study, while at the same time, the results obtained from the results of these analyses will be further utilize to test all of the hypotheses proposed in this study. However, before all of the data were further analyzed in this study, the respondents' profile assessment was conducted beforehand in order to further understand the profile and general chaarcteristics of the respondents participated in this study. Based on the results of the respondents' profile assessment, authors would like to conclude that most of the respondents are female $(73 \%)$, while most of the respondents were aged between 21-28 years old (65.48\%). Furthermore, most of the respondents hold a bachelor's degree $(83.18 \%)$, and that most of them had purchased any products from any B2C e-commerce companies in Indonesia between 6-10 times for the past 1 (one) year. After analyzing the results of the respondents' profile, all of the data then were further analyzed using PLS-SEM in order to assess the impact between variables included in this study.

\section{RESULTS AND DISCUSSIONS}

All of the data gathered from the respondents were analyzed and assessed using PLS-SEM method by using SmartPLS 3.3.2 software. In terms of analyzing all of the data using PLS-SEM, a two-step data analyses method should be conducted before authors could test the hypotheses proposed in this study, in which these two-step data analyses methods were the outer model measurement analysis, and the inner model measurement analysis.

\section{Outer Model Measurement Analysis and Inner Model Analysis Measurement Analysis}

The outer model measurement analysis required to be conducted in order to test and assess whether or not all of the data included and gathered from the respondents were valid and reliable. In this case, there are several aspects or criteria which should be satisfied in order to enable the authors to conclude that all of the data obtained in this study were valid and reliable, in which these criteria or aspects are: The AVE value of each variable should be above 0.5 , the factor loadings value of each indicators should be greater than 0.6 , the value of composite reliability of every variables should be greater than 0.7 , and the square root of AVE value between variables should be greater than the correlational values between the variable and the other variables (fornell-larcker criterion) in order for the discriminant validity criteria to be satisfied in this study (Barclay et al., 1995; Henseler et al., 2016). 
It is only if all of these criteria or aspects in the outer model measurement analyses had been fulfilled or satisfied that the next step, which is the inner model measurement analyses could be conducted. Therefore, it could be concluded that the inner model measurement analyses were not allowed to be executed if all of the aspects in the outer model measurement haven't been fullt satisfied. The results of the outer model measurement analyses in this study were presented on table 1 and table 2 respectively.

Table 1. Results of the Outer Model Measurement (Both Validity and Reliability Analyses) Source: Data Analysis (2021)

\begin{tabular}{|c|c|c|c|c|c|}
\hline \\
\hline & Indicators & Variables & $\begin{array}{l}\text { Factor } \\
\text { Loading }\end{array}$ & C.R & AVE \\
\hline PE1 & Learning to use this website is easy for me & \multirow{4}{*}{$\begin{array}{l}\text { Perceived Ease } \\
\text { of Use }\end{array}$} & 0.794 & \multirow{4}{*}{0.809} & \multirow{4}{*}{0.516} \\
\hline PE2 & $\begin{array}{l}\text { It would be easy for me to become skillful at } \\
\text { understanding all features in this website }\end{array}$ & & 0.717 & & \\
\hline PE3 & $\begin{array}{c}\text { My interactions with the website are clear and } \\
\text { understandable }\end{array}$ & & 0.675 & & \\
\hline PE4 & I would find that it is easy to interact with this website & & 0.681 & & \\
\hline PS1 & $\begin{array}{l}\text { I think this website shows great concern for the security } \\
\text { of any transaction }\end{array}$ & \multirow{4}{*}{$\begin{array}{l}\text { Perceived } \\
\text { Security }\end{array}$} & 0.721 & \multirow{4}{*}{0.840} & \multirow{4}{*}{0.571} \\
\hline PS2 & $\begin{array}{l}\text { I think this website has mechanisms to ensure the safe } \\
\text { transmission of its users' information }\end{array}$ & & 0.906 & & \\
\hline PS3 & $\begin{array}{l}\text { When I send data to this website, I am sure that they will } \\
\text { not be intercepted by an unauthorized third party }\end{array}$ & & 0.743 & & \\
\hline PS4 & $\begin{array}{l}\text { The systems of this website have enough security } \\
\text { measures to protect my personal and financial } \\
\text { information }\end{array}$ & & 0.617 & & \\
\hline CS1 & $\begin{array}{l}\text { I am satisfied with my decision to use this online } \\
\text { shopping website. }\end{array}$ & \multirow{4}{*}{$\begin{array}{l}\text { Customer } \\
\text { Satisfaction }\end{array}$} & 0.729 & \multirow{4}{*}{0.798} & \multirow{4}{*}{0.500} \\
\hline CS2 & $\begin{array}{l}\text { Based on all my experience with this online shopping } \\
\text { website, I feel very satisfied }\end{array}$ & & 0.699 & & \\
\hline CS3 & $\begin{array}{l}\text { I think I did the right thing when I decided to use this } \\
\text { online shopping website }\end{array}$ & & 0.760 & & \\
\hline CS4 & $\begin{array}{l}\text { I am very pleased with my experience of interacting with } \\
\text { the website }\end{array}$ & & 0.692 & & \\
\hline RP1 & $\begin{array}{l}\text { I'd like to continue using this online shopping website to } \\
\text { purchase products }\end{array}$ & \multirow{4}{*}{$\begin{array}{l}\text { Repurchase } \\
\text { Intention }\end{array}$} & 0.691 & \multirow{4}{*}{0.813} & \multirow{4}{*}{0.519} \\
\hline RP2 & $\begin{array}{l}\text { It is likely that I will continue to purchase products from } \\
\text { this online shopping } \\
\text { website in the future }\end{array}$ & & 0.679 & & \\
\hline RP3 & $\begin{array}{l}\text { I intend to continue purchasing products from this online } \\
\text { shopping website }\end{array}$ & & 0.727 & & \\
\hline RP4 & $\begin{array}{l}\text { I will regularly buy the products that I need from this } \\
\text { website in the future }\end{array}$ & & 0.726 & & \\
\hline
\end{tabular}

Table 2. Results of the Discriminant Validity Analyses Source: Data Analysis (2021)

\begin{tabular}{ccccc}
\hline & PE & PS & RPI & SAT \\
\hline PE & $\mathbf{0 . 7 1 8}$ & & & \\
\hline PS & 0.568 & $\mathbf{0 . 7 5 6}$ & & \\
\hline RPI & 0.651 & 0.444 & $\mathbf{0 . 7 0 6}$ & $\mathbf{0 . 7 2 1}$ \\
\hline SAT & 0.635 & 0.608 & 0.633 & \\
\hline
\end{tabular}

Based on the results of the outer model measurement analyses presented on both table 1 and 2, it could be concluded that all aspects given in the outer model measurement analyses had been satisfied in this study, in which the AVE and composite reliability value of each and every 
variable had been greater than 0.5 and 0.7 respectively, while the factor loadings value of each indicator had also been greater than the minimum acceptance value of 0.6. Meanwhile, the square root of AVE of each variable (which were shown on the top of every column) had also been greater than the correlation value between the variable with the other variables, thus ensuring that the fornell-larcker criterion measuring the discriminant validity of this study had also been fulfilled. Therefore, based on the aforementioned results, it could be concluded that all aspects or criteria which should be satisfied in the outer model measurement analysis had been satisfied, thus enabling the inner model measurement analysis to be conducted afterwards.

Unlike in the outer model measurement analysis which measure the validity and the reliability of each data collected in this study, the inner model measurement analysis was conducted in order to measure the relationships between variables assessed in this study. Moreover, all of the results generated in the inner model measurement analysis will also be used as the basis on whether or not to support the hypotheses proposed in this study. The result of the inner model measurement analysis was presented on table 3 .

Table 3. Path Coeffciient Analysis and Hypotheses Testing Results Source: Data Analysis (2019)

\begin{tabular}{cccc}
\hline Relationships & T-Statistics & Conclusions & $\begin{array}{c}\text { Hypotheses } \\
\text { Testing } \\
\text { Conclusions }\end{array}$ \\
\hline $\begin{array}{c}\text { Perceived Ease of Use had a direct and positive } \\
\text { impact on Repurchase Intention }\end{array}$ & 4.311 & Significant & H1 Supported \\
\hline $\begin{array}{c}\text { Perceived Security had a direct and positive } \\
\text { impact on Repurchase Intention }\end{array}$ & 4.888 & Significant & H2 Supported \\
\hline $\begin{array}{c}\text { Perceived Ease of Use had a direct and positive } \\
\text { impact on Customer Satisfaction }\end{array}$ & 3.982 & Significant & H3 Supported \\
\hline $\begin{array}{c}\text { Perceived Security had a direct and positive } \\
\text { impact on Customer Satisfaction }\end{array}$ & 5.853 & Significant & H4 Supported \\
\hline $\begin{array}{c}\text { Customer Satisfaction had a direct and positive } \\
\text { impact on Repurchase Intention }\end{array}$ & 3.547 & Significant & H5 Supported \\
$\begin{array}{c}\text { Perceived Ease of Use had a direct and positive } \\
\text { impact on Repurchase Intention through } \\
\text { Customer Satisfaction }\end{array}$ & 2.378 & Significant & H6 Supported \\
\hline $\begin{array}{c}\text { Perceived Security had a direct and positive } \\
\text { impact on Repurchase Intention through } \\
\text { Customer Satisfaction }\end{array}$ & 3.029 & Significant & H7 Supported \\
\hline
\end{tabular}

\section{Discussions}

This study was conducted and commenced in order to assess and determine the impact that both perceived ease of use and perceived security had toward customer satisfaction and repurchase intention in the Indonesian B2C e-commerce sector. These results were in line with the results generated from previous similar studies which were conducted by Kim et al., (2012), Aren et al., (2013), Meilatinova (2021), and Lee \& Charles (2021), in which these studies had also found that either perceived ease of use or perceived security had a positive and significant impact toward both satisfaction and repurchase intention. Based on the results obtained from the data analyses, it could be concluded that both perceived ease of use and perceived security had a positive impact toward both customer satisfaction and repurchase intention, in which perceived security was found out to have a stronger impact toward both satisfaction and repurchase intention as compared to perceived ease of use. Furthermore, both perceived ease of use and perceived security also turned out to have a positive indirect impact toward repurchase intention through customer satisfaction. In regards with these results, it could be seen that both perceived 
ease of use and perceived security play an important and integral role in determining consumers' action, motivation and satisfaction while conducting or making any purchasing activities toward B2C e-commerce companies in Indonesia. In this case, consumers' perception and judgement regarding whether or not it will be difficult to learn and use the new system, layout, technology or features implemented by the e-commerce companies could affect their intention or motivation to keep using or browsing the website, while at the same time, such judgements or assessments could also affect consumers' satisfaction toward the e-commerce website itself, which eventually could have a significant effect in determining the consumers' intention to keep buying or purchasing any products or goods from the company. Meanwhile, other than consumers' judgement regarding the possibility of consumers encountering any kinds of difficulties while browsing a website, consumers or people's assessment regarding the safety or security strength of the platform or website developed by the companies could also affecting consumers' satisfaction and loyalty toward the company itself. It is mainly because since most of the transactional and payment activities were conducted virtually, it means that consumers should input and provide all of the necessary data required in order to complete the purchasing or transactional activities conducted by consumers. In this case, consumers mainly required to provide their credit card number, phone number, email address, home address, and any other kinds of information which might be regarded as "personal" or "private" information by some consumers. Therefore, it is important for companies to ensure that the systems or technologies built and implemented by the company is safe and secure enough to protect all of these personal data in order to prevent all of the personal data belong to the consumers being breached or stolen by irresponsible parties. When companies are able to develop such system, consumers tend to believe that it will be safe to conduct any kind of transactional activities on the website developed by the company, thus increasing their satisfaction toward the company, in which consumers' satisfactory feelings toward the company could eventually drive consumers to keep buying or purchasing any kind of goods from the same e-commerce companies in the future, while not being attracted or interested by any offerings offered by the other competing companies.

\section{CONCLUSIONS AND SUGGESTIONS}

This study was commenced in order to assess the impact of both perceived ease of use and perceived security toward satisfaction and repurchase intention both in a direct and indirecrt manner within the Indonesian B2C e-commerce sector. In regard with the results obtained on the data analyses, authors could conclude that both perceived ease of use and perceived security had a positive and significant impact on customer satisfaction and repurchase intention, both in a direct and indirect manner. Therefore, based on these conclusions, author suggest that B2C ecommerce companies operating their business in Indonesia should be able to keep developing and creating newer systems and technologies with a stronger security systems and components, which not only will increase the efficiency and effectiveness level regarding all of the transactional activities conducted within the website, but also in order to enhance consumers' believe and satisfaction toward the system developed by the companies, thus ensuring that consumers will keep making further purchasing activities toward the website.

Furthermore, based on the results of the data analyses conducted within this study, the relationship between Perceived Security and Customer Satisfaction yields the highest statistical value as compare to the other relationships. In this case, such results could indicate that compared to the other factors, consumers tend to put or prioritize the security level of a website as the most important aspect or factor which could shape consumers' satisfaction, which could ultimately lead to the formation of consumers' intention to make another transactional activity 
within the same website in the future. Therefore, authors would like to suggest to e-commerce compaies which operate their business in the Indonesian e-commerce market to constantly and continuously monitor, enhance, upgrade and maintaining the safety or security system implemented or installed within the website, in which not only that such strategy could reduce or prevent the probability or possibility that consumers' data (which were stored on the website) could get stolen by irresponsible parties, but also that such strategy could increase consumers' level of confidence toward the website and the system, which could ultimately affect consumers' level of satisfaction and repurchase intention toward the website or company.

Despite the rigorous and thorough nature of this research, several limitations still exist in this research. First of all, this research was conducted only in Jakarta, which might hamper the generalizability of this research. In this case, authors would like to recommend that future studies could conduct another study in the other cities (or even in the other countries) in order to enhance the generalizability of this topic. Furthermore, this study was speficially conducted in the B2C e-commerce sector, which might cause the results of this research unable to be generalized to the other industries. Therefore, authors strongly suggest that future studies could conduct the effect of the variables discussed in this study in the other industries in order to increase the generalizability of this topic.

\section{REFERENCES}

Amin, M., Rezaei, S., \& Abolghasemi, M. (2014). User satisfaction with mobile websites: the impact of perceived usefulness (PU), perceived ease of use (PEOU) and trust. Nankai Business Review International, 5(3), 258-274. http://dx.doi.org/10.1108/NBRI-01-2014$\underline{0005}$

Anugrah, F. T. (2020). Effect of Promotion and Ease of Use on Customer Satisfaction and Loyalty on OVO Application Users. Quantitative Economics and Management Studies, 1(1), 44-50. https://doi.org/10.35877/454RI.qems1177

Aren, S., Güzel, M., Kabaday1, E., \& Alpkan, L. (2013). Factors Affecting Repurchase Intention to Shop at the Same Website. Procedia - Social and Behavioral Sciences, 99, 536544. https://doi.org/10.1016/j.sbspro.2013.10.523

Baccarella, C.V., Wagner, T.F., Scheiner, C.W., Maier, L. and Voigt, K.-I. (2020), "Investigating consumer acceptance of autonomous technologies: the case of self-driving automobiles", European Journal of Innovation Management, Vol. ahead-of-print No. ahead-of-print. https://doi.org/10.1108/EJIM-09-2019-0245

Barclay, D., Higgins, C., and Thompson, R. (1995), The partial least squares (PLS) approach to casual modeling: Personal computer adoption and use as an illustration, Technology Studies, 2(2), 285-309

Carlos Roca, J., José García, J. and José de la Vega, J. (2009), "The importance of perceived trust, security and privacy in online trading systems", Information Management \& Computer Security, 17(2), 96-113. https://doi.org/10.1108/09685220910963983

Chellappa, R.K. and Pavlou, P.A. (2002), "Perceived information security, financial liability and consumer trust in electronic commerce transactions", Logistics Information Management, 15(5/6), 358-368. https://doi.org/10.1108/09576050210447046

Chiu, W. and Cho, H. (2019), "E-commerce brand: The effect of perceived brand leadership on consumers' satisfaction and repurchase intention on e-commerce websites", Asia Pacific Journal of Marketing and Logistics, Vol. ahead-of-print No. ahead-of-print. https://doi.org/10.1108/APJML-10-2018-0403

Cui, F., Lin, D, \& Huang, Y. (2015). The Impact of Perceived Security on Consumer E-Loyalty: A Study of Online Tourism Purchasing, 2015 IEEE First International Conference on Big 
Data Computing Service and Applications, Redwood City, CA, 2015, pp. 314-322, doi: 10.1109/BigDataService.2015.41.

Falk, T., Kunz, W.H., Schepers, J. and Mrozek, A.J. (2016), "How mobile payment influences the overall store price image", Journal of Business Research, 69(7), 2417-2423

Filieri, R., Chen, W. and Lal Dey, B. (2017), "The importance of enhancing, maintaining and saving face in smartphone repurchase intentions of Chinese early adopters: An exploratory study", Information Technology \& People, 30(3), 629-652. https://doi.org/10.1108/ITP-092015-0230

Garcia, J.M., Freire, O.B.D.L., Santos, E.B.A. and Andrade, J. (2020), "Factors affecting satisfaction and loyalty to online group buying", Revista de Gestão, 27(3), 211-228. https://doi.org/10.1108/REGE-02-2018-0037

Gefen, D., Karahanna, E. \& Straub, D.W. (2003). Trust and TAM in online shopping: an integrated_model, MIS Quarterly, 27(1), 51-90

Ha, H.-Y. and Pan, H. (2018), "The evolution of perceived security: the temporal role of SNS information perceptions", Internet Research, 28(4), 1055-1078. https://doi.org/10.1108/IntR-02-2017-0047

Henseler, J., Hubona, G. and Ray, P.A. (2016), "Using PLS path modeling in new technology research: updated guidelines", Industrial Management \& Data Systems, 116(1), 2-20. https://doi.org/10.1108/IMDS-09-2015-0382

Hoogland, J. J., \& Boomsma, A. (1998). Robustness studies in covariance structure modeling An overview and a meta-analysis. Sociological Methods \& Research, 26(3), 329-367. https://doi.org/10.1177\%2F0049124198026003003

Keni, K. (2020). How Perceived Usefulness and Perceived Ease of Use Affecting Intent to Repurchase? Jurnal Manajemen, 24(3), 481-496. http://dx.doi.org/10.24912/jm.v24i3.680

Keni, K., Tjoe, H., Wilson, N., and Negara, E.S. (2020). The Effect of Perceived Security, Ease of Use and Perceived Usefulness on Intention to Use Towards Mobile Payment Services in Indonesia, Proceedings of the 2nd Tarumanagara International Conference on the Applications of Social Sciences and Humanities (TICASH 2020), https://dx.doi.org/10.2991/assehr.k.201209.010

Kim, C., Galliers, R. D., Shin, N., Ryoo, J.-H., \& Kim, J. (2012). Factors influencing Internet shopping value and customer repurchase intention. Electronic Commerce Research and Applications, 11(4), 374-387. https://doi.org/10.1016/j.elerap.2012.04.002

Kline, R. B. (2016). Principles and practice of structural equation modeling (4th ed.). Guilford Press

Laforet, S. and Li, X. (2005), "Consumers' attitudes towards online and mobile banking in China", International Journal of Bank Marketing, 23(5), 362-380

Langga, A., Kusumawati, A. and Alhabsji, T. (2020), "Intensive distribution and sales promotion for improving customer-based brand equity (CBBE), re-purchase intention and word-ofmouth (WOM)", Journal of Economic and Administrative Sciences, Vol. ahead-of-print No. ahead-of-print. https://doi.org/10.1108/JEAS-03-2019-0041

Lee, L., and Charles, V. (2021). The impact of consumers' perceptions regarding the ethics of online retailers and promotional strategy on their repurchase intention, International $\begin{array}{lllll}\text { Journal of Information } & \text { Management, } & 57, & \end{array}$ https://doi.org/10.1016/j.ijinfomgt.2020.102264

Meilatinova, N. (2021). Social commerce: Factors affecting customer repurchase and word-ofmouth intentions, International Journal of Information Management, 57, 102300. https://doi.org/10.1016/j.ijinfomgt.2020.102300 
Nadeem, M.A., Liu, Z., Pitafi, A.H., Younis, A. and Xu, Y. (2020), "Investigating the repurchase intention of Bitcoin: empirical evidence from China", Data Technologies and Applications, 54(5), 625-642. https://doi.org/10.1108/DTA-10-2019-0182

Oyedele, A., Saldivar, R., Hernandez, M.D. and Goenner, E. (2018), "Modeling satisfaction and repurchase intentions of mobile smart wristbands: the role of social mindfulness and perceived value", Young Consumers, 19(3), 237-250. https://doi.org/10.1108/YC-09-2017$\underline{00737}$

Pipitwanichakarn, T. and Wongtada, N. (2020). The role online review on mobile commerce adoption: an inclusive growth context, Journal of Asia Business Studies, 14(5), 759-778. https://doi.org/10.1108/JABS-02-2019-0060

Shams, G., Rather, R., Abdur Rehman, M. and Lodhi, R.N. (2020), "Hospitality-based service recovery, outcome favourability, satisfaction with service recovery and consequent customer loyalty: an empirical analysis", International Journal of Culture, Tourism and Hospitality Research, Vol. ahead-of-print No. ahead-of-print. https://doi.org/10.1108/IJCTHR-04-2020-0079

Singh, S., Sahni, M.M. and Kovid, R.K. (2020), "What drives FinTech adoption? A multimethod evaluation using an adapted technology acceptance model", Management Decision, 58(8), 1675-1697. https://doi.org/10.1108/MD-09-2019-1318

Slack, N., Singh, G. and Sharma, S. (2020), "The effect of supermarket service quality dimensions and customer satisfaction on customer loyalty and disloyalty dimensions", International Journal of Quality and Service Sciences, 12(3), 297-318. https://doi.org/10.1108/IJQSS-10-2019-0114

Tren dan Peluang Industri E-Commerce di Indonesia 2020. (2020, February 06). Retrieved January 08, 2021, from https://www.cnnindonesia.com/teknologi/20200205204206-206472064/tren-dan-peluang-industri-e-commerce-di-indonesia-2020

Trinh, H.N., Tran, H.H. and Vuong, D.H.Q. (2020), "Determinants of consumers' intention to use credit card: a perspective of multifaceted perceived risk", Asian Journal of Economics and Banking, 4(3), 105-120. https://doi.org/10.1108/AJEB-06-2020-0018

Trivedi, S.K. and Yadav, M. (2020), "Repurchase intentions in Y generation: mediation of trust and e-satisfaction", Marketing Intelligence \& Planning, 38(4), 401-415. https://doi.org/10.1108/MIP-02-2019-0072

Tu, C-C., Fang, K., \& Lin, C-Y. (2012). Perceived Ease of Use, Trust, and Satisfaction as Determinants of Loyalty in e-Auction Marketplace. Journal of Computers, 7(3), 645-652.

Undale, S., Kulkarni, A. and Patil, H. (2020), "Perceived eWallet security: impact of COVID-19 pandemic", Vilakshan - XIMB Journal of Management, Vol. ahead-of-print No. ahead-ofprint. https://doi.org/10.1108/XJM-07-2020-0022

Wang, Y., Anderson, J., Joo, S.-J. and Huscroft, J.R. (2019), "The leniency of return policy and consumers' repurchase intention in online retailing", Industrial Management \& Data Systems, 120(1), 21-39. https://doi.org/10.1108/IMDS-01-2019-0016

Wilson, N. (2018). The Impact of Service Quality and Brand Image Toward Customer Loyalty in The Indonesian Airlines Industry, Jurnal Manajemen Indonesia. 18(3), 222-234. https://doi.org/10.25124/jmi.v18i3.1734

Wilson, N. (2019). The Impact of Perceived Usefulness and Perceived Ease-of-Use toward Repurchase Intention in the Indonesian E-Commerce Industry, Jurnal Manajemen Indonesia. 19(3), 241-249. https://doi.org/10.25124/jmi.v19i3.2412

Wilson, N. (2020). The Impact of Service Quality and Corporate Reputation Toward Loyalty in The Indonesian Hospitality Sector, Jurnal Muara Ilmu Ekonomi dan Bisnis, 4(1), 1-9. http://dx.doi.org/10.24912/jmieb.v4i1.6925 
Wilson, N. (2020). Trust Vs Satisfaction: Which One is More Important in Mediating the Impact of Website Quality Towards Customer Loyalty in The Indonesian E-Commerce Industry? Proceedings of the International Conference on Management, Accounting, and Economy (ICMAE 2020), https://dx.doi.org/10.2991/aebmr.k.200915.003

Wilson, N., and Keni, K. (2018). Pengaruh Website Design Quality dan Kualitas Jasa Terhadap Repurchase Intention: Variabel Trust Sebagai Variabel Mediasi, Jurnal Manajemen dan Pemasaran Jasa, 11(2), 291- 310. http://dx.doi.org/10.25105/jmpj.v11i2.3006

Wilson, N., Keni, K., and Tan, P.H.P. (2019). The Effect of Website Design Quality and Service Quality on Repurchase Intention in the E-commerce Industry: A Cross-Continental Analysis, Gadjah Mada International Journal of Business, 21(2), 187-222. https://doi.org/10.22146/gamaijb.33665

$\mathrm{Xu}, \mathrm{H}$. (2013). The Effect of Perceived Security on Consumers' Intent to Use: Satisfaction and Loyalty to M-Commerce in China, Journal of Electronic Commerce in Organization, 11(4), 37-51. 10.4018/jeco.2013100103

Zhou, T., Lu, Y., \& Wang, B. (2009). The relative importance of website design quality and service quality in determining consumers' online repurchase behavior. Information Systems Management, 26(4), 327-337. https://doi.org/10.1080/10580530903245663 